\title{
Physical activity, dietary intake and quality of life during COVID-19 lockdown in patients awaiting transcatheter aortic valve implantation
}

\author{
D. van Erck (iD - C. D. Dolman · M. Snaterse - M. Tieland · A. H. G. Driessen · P. J. M. Weijs · W. J. M. Scholte op \\ Reimer · J. P. Henriques · J. D. Schoufour
}

Accepted: 24 June 2021 / Published online: 9 August 2021

(C) The Author(s) 2021

\begin{abstract}
Background The COVID-19 pandemic has led to a national lockdown in the Netherlands, which also affected transcatheter aortic valve implantation (TAVI) patients. The objective of the study was to describe physical activity, dietary intake and quality of life (QoL) in patients on the waiting list for TAVI prelockdown and during lockdown.

Methods Consecutive patients awaiting TAVI at the Amsterdam University Medical Centers, the Netherlands were included. Measurements were self-reported effect of lockdown, physical activity, dietary intake and QoL.

Results In total, 58 patients (median age 80, interquartile range (IQR) 76-84, 45\% female) were observed pre-lockdown and 16 patients (median age 78, IQR $76-82,25 \%$ female) during lockdown. Ten of the 16 patients during lockdown reported a decline in physical activity. However, we observed a median num-
\end{abstract}

ber of 5861 steps a day (IQR 4579-7074) pre-lockdown and 8404 steps a day (IQR 7653-10,829) during lockdown. Median daily protein intake was $69 \mathrm{~g}$ (IQR 59-82) pre-lockdown and 90 g (IQR 68-107) during lockdown. Self-rated health on a visual analogue scale was 63 points (IQR 51-74) pre-lockdown and 73 points (IQR 65-86) during lockdown.

Conclusions More than half of the patients during lockdown reported less physical activity, while we observed a higher number of steps a day, a similar dietary intake and a higher QoL. Therefore, patients on the TAVI waiting list appeared to be able to cope with the lockdown measures.

Keywords Exercise - Transcatheter aortic valve implantation · COVID-19 - Quality of life
D. van Erck $(\varangle)$ · W. J. M. Scholte op Reimer · J. P. Henriques Department of Cardiology, Amsterdam University Medical Centers, location Academic Medical Center, University of Amsterdam, Amsterdam, The Netherlands d.vanerck@amsterdamumc.nl

\section{D. Dolman · A. H. G. Driessen}

Department of Cardiothoracic Surgery, Amsterdam University Medical Centers, location Academic Medical Center, University of Amsterdam, Amsterdam, The Netherlands

M. Snaterse · W. J. M. Scholte op Reimer · J. D. Schoufour Faculty Health, Center of Expertise Urban Vitality, Amsterdam University of Applied Sciences, Amsterdam, The Netherlands

M. Tieland · P. J. M. Weijs · J. D. Schoufour Faculty of Sports and Nutrition, Center of Expertise Urban Vitality, Amsterdam University of Applied Sciences, Amsterdam, The Netherlands

\section{What's new?}

- In this study, most patients waiting for transcatheter aortic valve implantation (TAVI) reported engaging in less physical activity but doing extra activities during the COVID-19 lockdown in the spring of 2020.

- Physical activity level was higher during the lockdown than before the lockdown.

- Dietary intake was similar during and before the lockdown.

- Quality of life was higher during the lockdown than before the lockdown. 


\section{Introduction}

The outbreak of coronavirus disease 2019 (COVID19) has been declared a public health emergency and most countries have introduced measures to slow down the spread, for example a nationwide lockdown. Older adults on the waiting list for a cardiac intervention such as transcatheter aortic valve implantation (TAVI) can experience negative effects of the COVID-19 measures in two ways.

First, this patient group has a significant risk of becoming seriously ill if they were infected with severe acute respiratory syndrome coronavirus 2 (SARS$\mathrm{CoV}-2)$, as they are generally older than 70 years and cardiac patients are at higher risk of SARS-CoV-2 infection [1]. Due to their high-risk status, they were strongly advised to minimalise social contact, stay at home as much as possible and not to have visitors during the lockdown.

Second, hospitals were overwhelmed with COVID19 patients, which caused regular care to be postponed. Patients on the waiting list for a cardiac intervention had to deal with their health problems longer, such as shortness of breath and tiredness, and may potentially have been at higher risk of death. Additionally, patients are increasingly inactive in the period before a cardiac intervention $[2,3]$. The combination of long-term passive waiting for treatment, the persistence of health problems, and the lack of activities and social contact could lead to a severe decline in physical activity, dietary intake and quality of life (QoL). Insufficient physical activity and insufficient protein intake lead to less muscle mass, decreased physical functioning, less independency, early mortality and a further decline in QoL $[4,5]$.

Several studies have indicated that individuals experience a decrease in physical activity level, dietary intake and QoL due to lockdown measures [6-9]. However, studies measuring physical activity, dietary intake and QoL among TAVI patients during lockdown are currently lacking. Therefore, we aimed to describe the physical activity, dietary intake and QoL of patients on the waiting list for TAVI pre-lockdown and during lockdown.

\section{Methods}

\section{Study design and population}

All consecutive preoperative patients discussed in the Heart Team and accepted for a transfemoral TAVI at the Amsterdam University Medical Centers in Amsterdam, the Netherlands were asked to participate in this cross-sectional observational study. The study was approved by the hospital's ethics committee and patients provided informed consent.

Pre-lockdown data were part of two cohort studies. The first study focused on dietary intake and data were collected from May 2019 until January 2020. The second study focused on physical activity and QoL, which started data collection in January 2020 but had to stop in March 2020 because of the COVID-19 pandemic. From 12 March through 1 July 2020, we continued data collection on all three outcome measures, albeit in a modified form, by amending our methods to the COVID-19 protective measures. This meant patient inclusion and interview-based questionnaires were carried out by telephone and an activity tracker was sent to patients by mail after disinfection.

\section{Data collection and processing}

The patients who were included during lockdown were asked three multiple choice questions on perceived effects of the COVID-19 measures on their physical activity level and dietary intake.

Table 1 Characteristics of patients on waiting list for transcatheter aortic valve implantation, pre-lockdown and during lockdown

\begin{tabular}{|c|c|c|c|c|}
\hline Characteristic & $\begin{array}{l}\text { Pre-lockdown } \\
\text { group (dietary } \\
\text { intake) }(n=44)\end{array}$ & $\begin{array}{l}\text { Pre-lockdown } \\
\text { group (PA and } \\
\text { QoL) }(n=14)\end{array}$ & $\begin{array}{l}\text { Lockdown } \\
\text { group }(n=16)\end{array}$ & $P$-valu \\
\hline Age, years & $80(76-83)$ & $81(79-85)$ & $78(76-82)$ & 0.406 \\
\hline Female sex & $21(47.7)$ & $5(35.7)$ & $4(25.0)$ & 0.262 \\
\hline COPD & $7(15.9)$ & $2(14.3)$ & $1(6.2)$ & 0.623 \\
\hline DM & $16(36.4)$ & $4(28.6)$ & $3(18.8)$ & 0.417 \\
\hline Hypertension & $31(70.5)$ & $9(64.3)$ & $11(68.8)$ & 0.910 \\
\hline \multicolumn{4}{|l|}{ NYHA class } & \multirow[t]{5}{*}{0.020} \\
\hline 1 & $3(6.8)$ & $3(21.4)$ & $3(18.8)$ & \\
\hline ॥ & $16(36.4)$ & $9(64.3)$ & $11(68.8)$ & \\
\hline III & $20(45.5)$ & $2(14.3)$ & $2(12.5)$ & \\
\hline IV & $5(11.4)$ & 0 & 0 & \\
\hline \multicolumn{4}{|l|}{ LVEF } & \multirow[t]{5}{*}{0.238} \\
\hline Good (>50\%) & $34(77.3)$ & $10(76.9)$ & $11(68.8)$ & \\
\hline $\begin{array}{l}\text { Moderate } \\
(31-50 \%)\end{array}$ & $10(22.7)$ & $2(15.4)$ & $5(31.2)$ & \\
\hline $\begin{array}{l}\text { Poor } \\
(21-30 \%)\end{array}$ & 0 & $1(7.7)$ & 0 & \\
\hline $\begin{array}{l}\text { Very poor } \\
(\leq 20 \%)\end{array}$ & 0 & 0 & 0 & \\
\hline AVA & $0.84 \pm 0.16$ & $0.79 \pm 0.15$ & $0.84 \pm 0.15$ & 0.578 \\
\hline $\begin{array}{l}\text { Maximum } \\
\text { gradient }\end{array}$ & $67.70 \pm 17.22$ & $65.07 \pm 20.20$ & $65.41 \pm 16.16$ & 0.840 \\
\hline STS score & $\begin{array}{l}2.01 \\
(1.61-2.59)\end{array}$ & $\begin{array}{c}1.80 \\
(1.18-2.60)\end{array}$ & $\begin{array}{c}1.38 \\
(1.14-1.71)\end{array}$ & 0.073 \\
\hline \multicolumn{4}{|c|}{ Edmonton frailty score ${ }^{\mathrm{a}}$} & \multirow[t]{5}{*}{0.471} \\
\hline No frailty & $31(70.5)$ & $11(78.6)$ & $14(93.3)$ & \\
\hline Mild frailty & $10(22.7)$ & $2(14.3)$ & $1(6.7)$ & \\
\hline $\begin{array}{l}\text { Moderate } \\
\text { frailty }\end{array}$ & $3(6.8)$ & $1(7.1)$ & 0 & \\
\hline Severe frailty & 0 & 0 & 0 & \\
\hline
\end{tabular}

Data are median (interquartile range), $n(\%)$ or mean \pm standard deviation $P A$ physical activity, QoL quality of life, COPD chronic obstructive pulmonary disease, DM diabetes mellitus, NYHA New York Heart Association, LVEF left ventricular ejection fraction, AVA aortic valve area, STS Society of Thoracic Surgeons

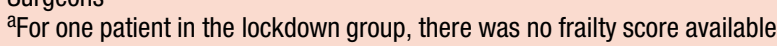


Fig. 1 Study flow diagram. $P A$ physical activity, QoL quality of life

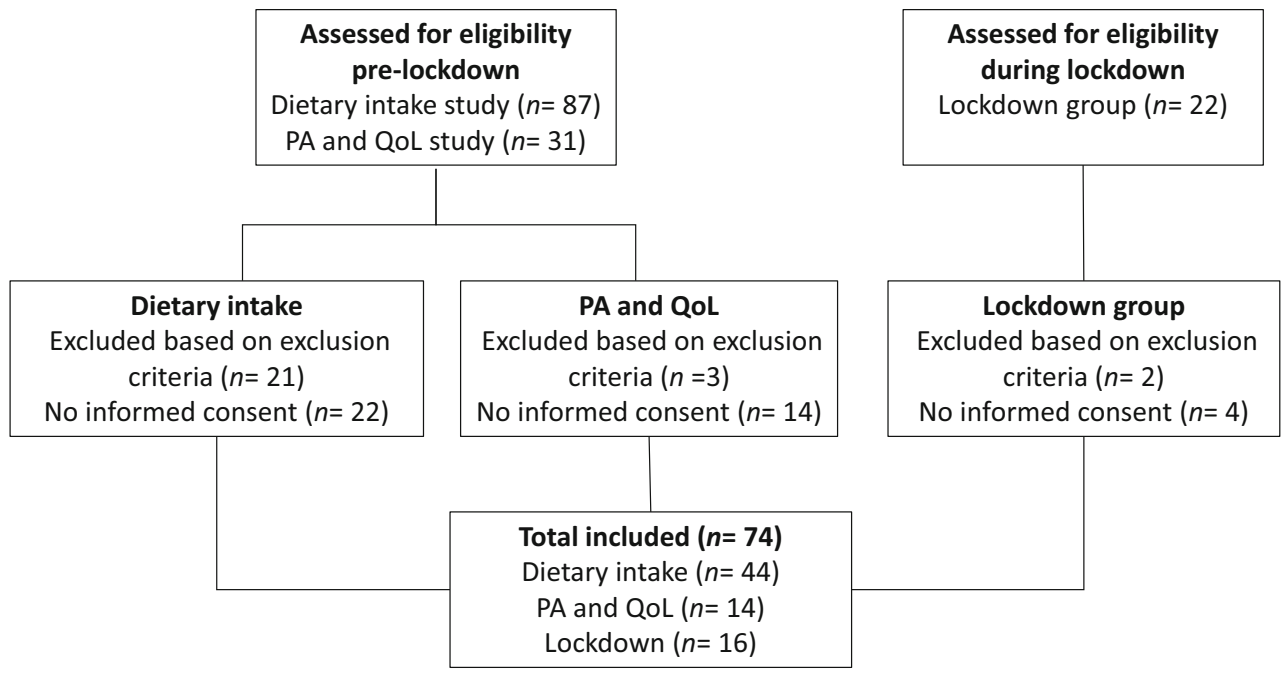

Physical activity and sedentary time were objectively measured as time-stamped steps with the Stepwatch 4 (Modus Health LLC, Edmonds, WA, USA), which is a valid tool to determine physical activity in older adults with normal, slow or irregular gait speed [10]. The Stepwatch had to be worn for 7 consecutive days during every waking hour for at least $12 \mathrm{~h}$ per day. Data were visually checked for completeness and patients with more than 3 days of complete data were included in the analysis. Thresholds for moderate and vigorous intensity were 100 and 130 steps per minute, respectively [11].

Dietary intake was determined with a 3-consecutive day dietary record. To increase validity, a trained researcher contacted each participant afterwards to discuss and complete the record [12]. To minimise recall bias, the dietary record was filled in three days before the meeting with the trained researcher. Day type (week or weekend day) was not taken into consideration as the difference in dietary intake between week and weekend days is minimal in older patients [13]. The dietary intake was converted to nutrient intake with the Dutch National Food Composition Database of 2016 [14].

Health-related QoL was determined with the EuroQol 5 Dimensions, which includes self-rated health on a vertical visual analogue scale (VAS) [15].

\section{Statistical analysis}

Data are presented as mean and standard deviation (SD) for normally distributed data or median and interquartile range (IQR) for non-normally distributed data. Differences between groups were determined with an independent-sample $t$-test or Mann-Whitney $U$ test depending on normality and with a chisquare or Fisher's exact test for categorical data. Fischer's exact test was used when the expected count was $<5$. A $p$-value $<0.05$ was considered statisti- cally significant. Analyses were performed in RStudio (v3.6.0).

\section{Results}

The patient selection process is shown in Fig. 1. In total, 140 patients were assessed; 40 patients did not give consent. The pre-lockdown group consisted of 58 patients and the lockdown group of 16 patients. Median age was 80 years (IQR 76-84) in the pre-lockdown group and 78 years (IQR 76-82) in the lockdown group (Tab. 1). In the pre-lockdown group, $45 \%$ of the patients was female versus $25 \%$ of the patients in the lockdown group. Average waiting time between acceptation for TAVI and treatment was comparable: 50.8 days (SD 27.8) pre-lockdown and 55.8 (SD 40.4) during lockdown. None of the patients in either group died before TAVI.

The comprehensive results are presented in Tab. 2 . In brief, 10 of the 16 patients in the lockdown group reported a decline in physical activity due to the lockdown measures and 9 did extra home-based activities. One patient reported a change in dietary intake.

The median number of steps a day was 5861 (IQR 4579-7074) pre-lockdown versus 8404 (IQR 7653-10,829) during lockdown. In both groups combined, 2 of the 26 patients had a sedentary time of less than $8 \mathrm{~h}$. The median energy intake was $1582 \mathrm{kcal} /$ day (IQR 1436-1917) in the pre-lockdown group and $1813 \mathrm{kcal} /$ day (IQR 1466-2400) in the lockdown group, whereas the median daily protein intake was $69 \mathrm{~g}$ (IQR 59-82) and $90 \mathrm{~g}$ (IQR 68-107), respectively. Ten of the 56 patients for whom data on the protein intake were available, met the recommended protein intake of $1.2 \mathrm{~g} / \mathrm{kg}$ per day. Lastly, the median VAS score (QoL) was 63 (IQR 51-74) pre-lockdown and 73 (IQR 65-86) during lockdown. 


\section{Advertisement placed here.}

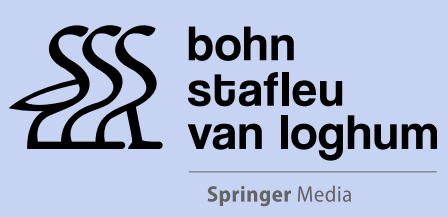

Houten 2021 


\section{Advertisement placed here.}

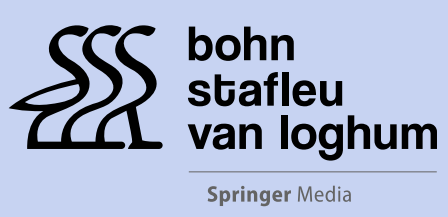

Houten 2021 
Table 2 Physical activity, dietary intake and quality of life in patients on waiting list for transcatheter aortic valve implantation, pre-lockdown and during lockdown

\begin{tabular}{|c|c|c|c|}
\hline Variable & Pre-lockdown group & Lockdown group & $P$-value \\
\hline $\begin{array}{l}\text { Self-reported change } \\
\text { in physical activity }\end{array}$ & & $(n=16)$ & \\
\hline More & & $1(6)$ & \\
\hline Similar & & $5(31)$ & \\
\hline Somewhat less & & $8(50)$ & \\
\hline Much less & & $2(13)$ & \\
\hline $\begin{array}{l}\text { Extra home-based } \\
\text { activities }\end{array}$ & & $9(56)$ & \\
\hline $\begin{array}{l}\text { Self-reported change } \\
\text { in dietary intake }\end{array}$ & & $1(6)$ & \\
\hline Physical activity ${ }^{a}$ & $(n=13)$ & $(n=13)$ & \\
\hline Number of steps/day & $5861(4579-7074)$ & $8404(7653-10,829)$ & 0.02 \\
\hline \multicolumn{4}{|c|}{ Intensity, $\min /$ week } \\
\hline Light intensity & $1698 \pm 519$ & $2047 \pm 437$ & 0.08 \\
\hline Moderate intensity & $14(4-70)$ & $69(0-145)$ & 0.47 \\
\hline Vigorous intensity & 0 & 0 & 0.25 \\
\hline $\begin{array}{l}\text { Time out of bed, } \\
\text { hours/day }\end{array}$ & $14.0(13.1-14.5)$ & $14.7(14.1-15.3)$ & 0.05 \\
\hline $\begin{array}{l}\text { Sedentary time, } \\
\text { hours/day }\end{array}$ & $9.57 \pm 0.99$ & $9.45 \pm 1.29$ & 0.79 \\
\hline Dietary intake $e^{b}$ & $(n=44)$ & $(n=12)$ & \\
\hline $\begin{array}{l}\text { Energy intake, } \\
\text { Kcal/day }\end{array}$ & $1582(1436-1917)$ & $1813(1466-2400)$ & 0.23 \\
\hline $\begin{array}{l}\text { Protein intake, } \\
\text { gram/day }\end{array}$ & $69(59-82)$ & $90(68-107)$ & 0.09 \\
\hline $\begin{array}{l}\text { Protein intake, } \\
\text { gram/kg per day }\end{array}$ & $0.93(0.75-1.09)$ & $1.09(0.84-1.30)$ & 0.12 \\
\hline $\begin{array}{l}\text { Carbohydrate intake, } \\
\text { gram/day }\end{array}$ & $183(146-224)$ & $201(164-243)$ & 0.23 \\
\hline Fat intake, gram/day & 60 (49-72) & $57(49-84)$ & 0.90 \\
\hline Quality of life $e^{c}$ & $(n=14)$ & $(n=16)$ & \\
\hline Health status ${ }^{d}$ & $63(51-74)$ & $73(65-86)$ & 0.05 \\
\hline \multicolumn{3}{|l|}{ Mobility } & \multirow[t]{4}{*}{$>0.99$} \\
\hline No problems & $10(71)$ & $11(69)$ & \\
\hline Some problems & $4(29)$ & $5(31)$ & \\
\hline Severe problems & 0 & 0 & \\
\hline \multicolumn{3}{|l|}{ Self-care } & \multirow[t]{4}{*}{0.47} \\
\hline No problems & $13(93)$ & $16(100)$ & \\
\hline Some problem & $1(7)$ & 0 & \\
\hline Severe problems & 0 & 0 & \\
\hline \multicolumn{4}{|l|}{$A D L$} \\
\hline No problems & $11(79)$ & $15(94)$ & \multirow[t]{3}{*}{0.32} \\
\hline Some problems & $3(21)$ & $1(6)$ & \\
\hline Severe problems & 0 & 0 & \\
\hline \multicolumn{3}{|l|}{ Pain } & \multirow[t]{4}{*}{$>0.99$} \\
\hline No pain & $10(71)$ & $12(75)$ & \\
\hline Some pain & $4(29)$ & $4(25)$ & \\
\hline Severe pain & 0 & 0 & \\
\hline
\end{tabular}

Table 2 (Continued)

\begin{tabular}{|c|c|c|c|}
\hline Variable & Pre-lockdown group & Lockdown group & $P$-value \\
\hline \multicolumn{3}{|l|}{ Depressive feelings } & \multirow[t]{4}{*}{0.85} \\
\hline $\begin{array}{l}\text { No depressive feel- } \\
\text { ings }\end{array}$ & $8(57)$ & $10(63)$ & \\
\hline $\begin{array}{l}\text { Some depressive } \\
\text { feelings }\end{array}$ & $5(36)$ & $6(37)$ & \\
\hline $\begin{array}{l}\text { Severe depressive } \\
\text { feelings }\end{array}$ & $1(7)$ & 0 & \\
\hline \multicolumn{3}{|l|}{ Memory } & \multirow[t]{4}{*}{$>0.99$} \\
\hline No problems & $11(79)$ & $12(75)$ & \\
\hline Some problem & $3(21)$ & $4(25)$ & \\
\hline Severe problems & 0 & 0 & \\
\hline \multicolumn{4}{|c|}{$\begin{array}{l}\text { Data are } n(\%) \text {, median (interquartile range) or mean } \pm \text { standard deviation } \\
\text { ADL Activities of Daily Living } \\
\text { aphysical activity assessed by Stepwatch } \\
\text { bDietary intake assessed by dietary record } \\
\text { 'Quality of life assessed by EuroQol } 5 \text { Dimensions } \\
\text { dHealth status assessed by visual analogue scale }\end{array}$} \\
\hline
\end{tabular}

\section{Discussion}

We observed that older cardiac patients awaiting TAVI who were included in our study during lockdown walked a higher number of steps, had a similar dietary intake and reported a higher QoL compared with those included pre-lockdown. Furthermore, most patients were sedentary and did not meet the recommended levels for physical activity and protein intake.

More than half of the patients experienced self-reported decline in physical activity due to the COVID19 measures. However, most of the patients who reported less physical activity also said they undertook extra activities. During the lockdown, much media attention was directed to physical activity. Combined with increased health awareness, this caused more interest in physical activity during the lockdown [16]. This increased awareness could have motivated patients to become more active and could therefore have resulted in their being more physically active [17].

In addition, seasonality could have affected the results. It is well known that during the spring (the studied lockdown took place in spring), people become more active when the days are longer and the weather is better. However, this effect is often less persistent in adults older than 75 years [18].

Although we observed a higher number of steps during lockdown, it is evident that both groups did not meet the recommended amount of physical activity and were sedentary. The intensity of most activity was light and fell far below the recommended $150 \mathrm{~min}$ at moderate or $75 \mathrm{~min}$ at vigorous intensity [19]. All but two patients had a total sedentary time of more than $8 \mathrm{~h}$, indicating a sedentary lifestyle, which is associated with early mortality [20]. Therefore, sedentary time needs to be decreased and activity at a moderate intensity needs to be increased in preoperative TAVI patients. 
For dietary intake, only one patient reported a change during the lockdown. This is consistent with our results that showed no differences in energy and macronutrient intake. In most of the patients in both groups, protein intake was below the recommended intake of $1.2 \mathrm{~g} / \mathrm{kg}$, while protein intake is very important to retain muscle mass and muscle function [21]. Therefore, protein intake in this patient group needs to be increased.

The VAS score for health status measured with the EuroQol 5 Dimensions was 10 points higher in the lockdown group than in the pre-lockdown group. There is an association between frailty, physical activity and QoL scores [22, 23]. In the lockdown group, 1 of the 16 patients was mildly frail (7\%), while 2 out of 14 patients in the pre-lockdown group were mildly frail and 1 patient was moderately frail $(21 \%)$. This could have resulted in a better health status in the lockdown group. Another explanation for the better quality of life could be the higher level of physical activity in the lockdown group [22]. A similar study in France and Switzerland showed that adults with increased activity during lockdown reported a higher physical health status [24].

\section{Study limitations}

One limitation of the study is possible selection bias. However, during the lockdown, all referred patients were treated similarly to the normal situation, and acceptation for TAVI was independent of frailty or severity of symptoms. Therefore, we do not expect a selection bias based on the procedures for TAVI. This is supported by a lack of major differences in the baseline characteristics.

Further limitations are the small sample size, possible seasonal effects and the inability to perform repeated measures. Based on the sample size, no hard conclusions can be drawn and we are only able to describe the data. In addition, a substantial part of the patients did not provide informed consent. As they were frailer, our findings cannot be generalised to the most frail patients awaiting TAVI [25].

Despite these limitations, the study offers a valuable first insight into the effects of lockdown measures on older cardiac patients.

\section{Conclusion}

This is the first study to measure physical activity, dietary intake and QoL in patients on the TAVI waiting list before and during a nationwide COVID-19 lockdown. Both groups had a sedentary lifestyle and insufficient protein intake. More than half of the patients reported a decline in physical activity level during lockdown, while a higher number of steps was observed. There were no meaningful differences in sedentary time and dietary intake, whereas QoL was higher during lockdown. These results offer a first in- sight into the effect of lockdown measures on patients awaiting TAVI. Since we observed no clear decline in physical activity, dietary intake and quality of life, older cardiac patients seem to be able to cope with the lockdown measures.

Acknowledgements D. van Erck and C. D. Dolman contributed equally to this work.

The authors thank Nadine Rijkers for support with inclusion and data collection.

Funding This work was supported by an internal grant from the Amsterdam University Medical Centers, location Academic Medical Center and the Amsterdam University of Applied Sciences (Hogeschool van Amsterdam) (171107/2017.03.xxx).

Conflict of interest D. van Erck, C. D. Dolman, M. Snaterse, M. Tieland, A. H. G. Driessen, P. J. M. Weijs, W. J. M. Scholte op Reimer, J. P. Henriques and J. D. Schoufour declare that they have no competing interests.

Open Access This article is licensed under a Creative Commons Attribution 4.0 International License, which permits use, sharing, adaptation, distribution and reproduction in any medium or format, as long as you give appropriate credit to the original author(s) and the source, provide a link to the Creative Commons licence, and indicate if changes were made. The images or other third party material in this article are included in the article's Creative Commons licence, unless indicated otherwise in a credit line to the material. If material is not included in the article's Creative Commons licence and your intended use is not permitted by statutory regulation or exceeds the permitted use, you will need to obtain permission directly from the copyright holder. To view a copy of this licence, visit http://creativecommons.org/licenses/by/4.0/.

\section{References}

1. Clerkin KJ, Fried JA, Raikhelkar J, et al. Coronavirus Disease 2019 (COVID-19) and Cardiovascular Disease. Circulation. 2020;141:1648-55.

2. Olsson K, Nilsson J, Hörnsten Å, Näslund U. Patients' selfreported function, symptoms and health-related quality of life before and 6 months after transcatheter aortic valve implantation and surgical aortic valve replacement. Eur J Cardiovasc Nurs. 2017;16:213-21.

3. Sathananthan J, Lauck S, Piazza N, et al. Habitual physical activity in older adults undergoing TAVR. JACC Cardiovasc Interv. 2019;12:781-9.

4. Koolhaas CM, Dhana K, van Rooij FJA, Schoufour JD, Hofman A, Franco OH. Physical activity types and healthrelated quality of life among middle-aged and elderly adults: The Rotterdam Study. J Nutr Health Aging. 2018;22:246-53.

5. Rasheed S, Woods RT. Malnutrition and quality of life in older people: a systematic review and meta-analysis. Ageing Res Rev. 2013;12:561-6.

6. Rogers NT, WaterlowNR, BrindleH, etal. Behavioral change towards reduced intensity physical activity is disproportionately prevalent among adults with serious health issues or self-perception of high risk during the UK COVID-19 Lockdown. Front Public Health. 2020;8:1-12.

7. Deschasaux-Tanguy M, Druesne-Pecollo N, Esseddik Y, et al. Diet and physical activity during the coronavirus disease 2019 (COVID-19) lockdown (march-May2020): results from 
the French Nutrinet-Santé cohort study. Am J Clin Nutr. 2021;113:924-38.

8. Samlani Z, Lemfadli Y, Errami A, Oubaha S, Krati K. The impact of the COVID-19 pandemic on quality of life and well-being in Morocco. Arch Community Med Public Health. 2020;6:130-4.

9. De Matos DG, Aidar FJ, de Almeida-Neto PF, et al. The impact of measures recommended by the government to limit the spread of coronavirus (COVID-19) on physical activitylevels, quality oflife, andmental health of Brazilians. Sustain. 2020;12:1-13.

10. Hergenroeder AL, Barone Gibbs B, Kotlarczyk MP, Kowalsky RJ, Perera S, Brach JS. Accuracy of objective physical activity monitors in measuring steps in older adults. GerontolGeriatr Med. 2018;4:1-5.

11. O'Brien MW, Kivell MJ, Wojcik WR, D'Entremont GR, Kimmerly DS, Fowles JR. Influence of Anthropometrics on steprate thresholds for moderate and vigorous physical activity in older adults: scientific modeling study. JMIR Aging. 2018;1:e12363.

12. Cantwell MM, Millen AE, Carroll R, et al. Nutritional epidemiology A debriefing session with a nutritionist can improve dietary assessment using food diaries. J Nutr. 2006;136:440-5.

13. Gingrich A, Rennekamp R, Brandl B, et al. Do aspects of protein intake vary across the week in healthy community-dwelling older adults?-An enable study. Nutrients. 2018;10:1-12.

14. Dutch Food Composition Table. NEVO-tabel: Nederlands Voedingsstoffenbestand 2016/NEVO Foundation. The Hague: Dutch Food Composition Table; 2016. https:// nevo-online.rivm.nl/.

15. Rabin R, De Charro F. EQ-5D: A measure of health status from the EuroQolGroup. Ann Med. 2001;33:337-43.

16. Ding D, Del Pozo Cruz B, Green MA, Bauman AE. Is the COVID-19 lockdown nudging people to be more active: a big data analysis. Br J Sports Med. 2020;54:2019-20.
17. Franco MR, Tong A, Howard K, et al. Older people' s perspectives on participation in physical activity: a systematic review and thematic synthesis of qualitative literature. $\mathrm{Br} J$ Sports Med. 2015;49:1268-76.

18. Cepeda M, Koolhaas CM, van Rooij FJA et al. Seasonality of physical activity, sedentary behavior, and sleep in a middle-aged and elderly population: the Rotterdam study. Maturitas. 2018;110:41-50.

19. Piercy KL, Troiano RP, Ballard RM, et al. The physical activity guidelines for Americans. J Am Med Assoc. 2018;320:2020-8.

20. De Rezende LFM, Rey-López JP, Matsudo VKR, Luiz ODC. Sedentary behavior and health outcomes among older adults: a systematic review. BMC Public Health. 2014;14:1-9.

21. Deutz NEP, Bauer JM, Barazzoni R, et al. Protein intake and exercise for optimal muscle function with aging: recommendations from the ESPEN Expert Group. Clin Nutr. 2014;33:929-36.

22. Lobo A, Santos P, Carvalho J, Mota J. Relationship between intensity of physical activity and health-related quality of life in Portuguese institutionalized elderly. Geriatr Gerontol Int. 2008;8:284-90.

23. Kojima G, Iliffe S, Jivraj S, Walters K. Association between frailty and quality of life among community-dwelling older people: a systematic review and meta-analysis. JEpidemiol Community Health. 2016;70:716-21.

24. Cheval B, Sivaramakrishnan H, Maltagliati S, et al. Relationships between changes in self-reported physical activity, sedentary behaviour and health during the coronavirus (COVID-19) pandemic in France and Switzerland. J Sports Sci. 2021;39:699-704.

25. Hempenius L, Slaets JPJ, Boelens MAM, Van Asselt DZB, et al. Inclusion of frail elderly patients in clinical trials: Solutions to the problems. J Geriatr Oncol. 2013;4:26-31. 